\title{
Assessment of the On-the-Job Training Program of Business Administration Students of Kalinga State University
}

\author{
Gretchen Calagui Dawaton \\ College of Business, Entrepreneurship and Accountancy, Kalinga State University, Tabuk City, Kalinga, Philippines
}

Received November 25, 2020; Revised December 28, 2020; Accepted January 28, 2021

\section{Cite This Paper in the following Citation Styles}

(a): [1] Gretchen Calagui Dawaton, "Assessment of the On-the-Job Training Program of Business Administration Students of Kalinga State University," Universal Journal of Management, Vol. 9, No. 1, pp. 13 - 19, 2021. DOI: 10.13189/ujm.2021.090102.

(b): Gretchen Calagui Dawaton (2021). Assessment of the On-the-Job Training Program of Business Administration Students of Kalinga State University. Universal Journal of Management, 9(1), 13 - 19. DOI: 10.13189/ujm.2021.090102.

Copyright $@ 2021$ by authors, all rights reserved. Authors agree that this article remains permanently open access under the terms of the Creative Commons Attribution License 4.0 International License

\begin{abstract}
The study pursued to determine the perception of the business students on the effectiveness of the On-the-Job Training Program of the Kalinga State University in four areas, namely support of the college, pre-placement activities, support of the host agency, and effectiveness of the on-the-job training in terms of academic, personal and enterprise skills. The study used descriptive methods using a survey questionnaire as the primary tool for gathering the responses of two hundred thirty-nine respondents. The study revealed that the students perceived the OJT program of the University as average. Also, the common problems encountered by trainees were a mismatch of tasks with the course program, lack of supervision by the adviser and supervisor, limited time for OJT, and lack of proper orientation about the work. Thus, the University needs to strengthen its support to student trainees; improve pre-placement activities, and enhance host agencies' support to develop trainees' academic, personal, and entrepreneurial skills. The University needs to establish guidelines in choosing host agencies to ensure the relevance and quality of training provided to trainees are aligned to their chosen fields. The findings of this study can be used to improve OJT programs for undergraduate students to ensure students' competitiveness.
\end{abstract}

Keywords OJT Program, On-the-Job Training, Student Internship, Interns, Trainee

\section{Introduction}

Experiential learning is essential to make the teaching and learning process more effective for students in academic institutions, in which one of its major components is on-the-job training. As such, tertiary schools like Kalinga State University require students from different fields to undergo internships or on-the-job training as a prerequisite for graduation. The guidelines for students' internship for all Higher Education Institutions (HEIs) in the Philippines are provided in the CMO No. 104 series of 2017. In the said CMO, an internship is defined as the actual application of classroom learning to the real regular work environment such as commercial, industrial services, government

The internship program provides students opportunity to apply the theories they have learned from their classrooms, gain hands-on experiences in their fields, and develop their competencies and skills. (Jamil et al., 2013; Joseph et al., 2015; Mengistu \& Mahesh, 2019; Stansbie et al., 2016). Moreover, the OJT program allows students to have real-life experience in their future workplace and enterprises if they opt to become entrepreneurs, making them more competitive and competent as individuals. More importantly, on-the-job training helps in the formation of students to acquire professional work ethics.

On the other hand, the on-the-job training programs also provide the University opportunities for partnership and linkages, leading to its graduates' employment and 
better feedback mechanisms for curriculum improvement. The evaluation given by the supervisor of the trainee is beneficial to assess the weaknesses of the students and lacking the University in the preparedness of students in the real work scenario, thereby, achieving curriculum match with the needs of the industry. More importantly, proper implementation of the OJT program by establishing strong linkage and partnerships can help promote the curricular programs offered in the University, leading to an increase in enrolment, prestige, and support in terms of scholarships, grants and facilities (Divine et al., 2007).

The OJT program involves three parties; the trainee, the institution and, a reputable training host agency. The trainee is expected to follow the OJT program's guidelines, such as undergoing orientation before deployment, meeting the required number of hours to be completed, wearing uniforms, and following the agency's policies. The institution is expected to ensure that the host agency meets the qualifications for a reputable training host agency to ensure the students' security and the quality of training provided to them. The administrative effort and functions of the host agencies are essential in the OJT program (Karunaratne \& Perera, 2015; Renganathan et al., 2012). The host agencies are expected to provide adequate training opportunities for trainees and follow the conditions set in the Memorandum Agreements forged with the University. The university and host agencies expect the students to maximize learning through applications and practices, assist in the organizational works and operational tasks and activities, and be involved in problem-solving. However, the execution of the practicum is the host agencies' responsibility, and institutions do not have much training for their students. Thus, by adopting a negotiating interest approach in program planning, institutions can play some active roles in planning industrial activity and organizations. The Higher Education Institutions can improve their functions in organizing and managing the on-the-job training program by strengthening the partnerships with training providers.

Students who have gone for on-the-job training have shown improvement in their communication skills and manifested personal growth (Lim \& Mustafa, 2013; Streumer \& Kho, 2006). Also, allowing the graduating students to experience the real-work scenario will develop competencies and values to become efficient and effective professionals (Bernardo et al., 2014; Karunaratne \& Perera, 2015). Internship programs increase graduates' employability (Callanan \& Benzing, 2004; Gault et al., 2010; Mason et al., 2009). Students who have performed well in their OJT program were hired as employees after graduation. Most private entities prefer competent graduates, willing to be trained, and team player, responsible, result-oriented, and have high regard for the company (Laguador \& Ramos, 2014).
As technology advances, it also dramatically affects workplaces and how things are being done in different industries. And it is the academic institutions' responsibility to prepare a well-structured training program, which is comprehensive, relevant, and timely to make internships effective (Rosli et al., 2019).

As Kalinga State University aims to produce globally competitive graduates and gainfully employed relevant to their courses, students were required to undergo on-the-job training following the required number of hours as prescribed by the Commission on Higher Education. The BS Financial Management, BS Accountancy, and BS Office Administration students were required to undergo 400 hours either in private or government agencies. In comparison, the BS Entrepreneurship students were required to undergo 200 hours of training in private entities. After the students completed the required hours for their on-the-job training, they will be evaluated by the supervisor in the host agency and the practicum course adviser.

This study aims to assess the college's support to the students, the pre-placement activities, the support of the host agency, and the OJT program's effectiveness in developing students' academic, personal, and enterprise skills. This study will also help identify the areas of improvement in implementing the on-the-job training program at Kalinga State University. This study will also contribute to the body of knowledge relative to curriculum development and implementation of internship programs in the University and other Higher Education Institutions.

\section{Materials and Methods}

This quantitative study utilized a descriptive research method to assess the On-the-Job training program of Business Administration students. The researcher got the lists of students from the Registrar's Office per batch, and they were divided as follows: 65 students from batch 2014-2015, 85 students from batch 2015-2016, and 89 from batch 2016-2017. So, a total of two hundred and thirty-nine (239) students undergone their training from 2014-2017. Total sampling was used in the study. It can be gleaned in Table 1, the respondents' profiles in which two hundred eighteen (218) were females, and twenty (21) were males.

The questionnaire used was patterned from the research of Karunaratne K.and Perera N. (2015) and modified based on the objectives of the study. The questionnaire is divided into seven categories which are an assessment of the support provided by the college (4 items), evaluation of the efficiency of the pre-placement activities (3 items), assessment of the support of the host agency (6 items), the effectiveness of the OJT program in terms of academic skills (4 items), personal skills (6 items) and enterprise skills (6 items). So, the questionnaire consists of 29 items. 
The items were categorized according to the phases of the OJT program, the preparation, during, and after the OJT program. In the preparation phase, the students assess the support of the college and the effectiveness of the pre-placement activities conducted. Then, during the on-the-job training, the students assess the support of the host agency provided to them, and lastly, the students assess the effectiveness of the OJT program in terms of the development of their academic, personal, and enterprise skills.

Prior to the administration of the questionnaire, the researcher submitted a copy to the college research coordinator, OJT coordinator, and the College Dean for checking. Then, the College Dean endorsed the research proposal along with the research questionnaire to the Vice-President of Research and Extension of Kalinga State University for validation and approval. Upon receiving the notice of approval, the survey questionnaire was administered to the respondents through their emails and social media accounts. Some were administered personally with the other program chairmen, faculty, students in distributing and retrieving the survey questionnaires.

The data gathered were analyzed with the college statistician's assistance to ensure the correctness of computations and interpretations of results. The researcher also observed utmost confidentiality of the profiles of respondents to avoid biases in the analysis of data.

Table 1. Profile of the Respondents

\begin{tabular}{|c|c|c|}
\hline Profile Variables & $\begin{array}{c}\text { Frequency } \\
(\mathrm{n}=239)\end{array}$ & Percentage \\
\hline Courses & & \\
\hline BS Entrepreneurship & 32 & 13.39 \\
\hline BS Office Administration & 64 & 26.78 \\
\hline $\begin{array}{c}\text { BS Hotel \& Restaurant } \\
\text { Management }\end{array}$ & 63 & 26.36 \\
\hline BSBA-Financial Management & 72 & 30.13 \\
\hline BS Accountancy & 8 & 3.35 \\
\hline Gender & 21 & 8.79 \\
\hline Male & 218 & 91.21 \\
\hline Females & &
\end{tabular}

Table 2. Scale and Qualitative Description in Evaluating On-the-Job Training Program

\begin{tabular}{|c|c|c|c|}
\hline $\begin{array}{c}\text { Arbitrary } \\
\text { Values }\end{array}$ & Scale & Qualitative Description & Symbol \\
\hline 5 & $4.21-5.0$ & Strongly Agree & SA \\
\hline 4 & $3.41-4.20$ & Moderately Agree & MOA \\
\hline 3 & $2.61-3.40$ & Agree & $\mathrm{A}$ \\
\hline 2 & $1.81-2.60$ & Neither Agree or Disagree & NAD \\
\hline 1 & $1.00-1.80$ & Disagree & $\mathrm{D}$ \\
\hline
\end{tabular}

Finally, Table 1 presents the respondents' profile in which descriptive statistics like frequency and percentage were used and also mean was used to assess the different facets of the on-the-job training program. Table 2 presents the scale and qualitative description used in the evaluation.

\section{Results and Discussions}

Table 3. Assessment of College Support

\begin{tabular}{|c|c|c|}
\hline College Support Evaluation & $\begin{array}{c}\text { Weighted } \\
\text { Ave }\end{array}$ & $\mathrm{DE}$ \\
\hline $\begin{array}{c}\text { Establishment of good rapport between } \\
\text { the trainees and training provider }\end{array}$ & 3.21 & $\mathrm{~A}$ \\
\hline $\begin{array}{c}\text { Availability of adviser and other faculty } \\
\text { anytime during the training }\end{array}$ & 3.18 & $\mathrm{~A}$ \\
\hline $\begin{array}{c}\text { Prompt action from the adviser and other } \\
\text { faculty when issues arise }\end{array}$ & 3.23 & $\mathrm{~A}$ \\
\hline $\begin{array}{c}\text { Assistance provided by the adviser and } \\
\text { other faculty during training }\end{array}$ & 3.51 & $\mathrm{MOA}$ \\
\hline Total Weighted Average Mean & 3.28 & $\mathrm{~A}$ \\
\hline
\end{tabular}

Table 3 shows the assessment of students of the support provided by the college during their training. The table reveals that the students agree that the adviser for the on-the-job training and other faculty of the College of Business, Entrepreneurship, and Accountancy was helpful and respond promptly when problems arise during their training. This proves that the adviser, faculty, and the University administration's role is vital in attaining the objectives of the on-the-job training for the students.

Studies reveal that support students through monitoring and appropriate feedback mechanisms increase students' satisfaction and boost their self-confidence and enthusiasm towards their tasks (D'Abate et al., 2009; Jamil et al., 2013; Karunaratne \& Perera, 2019). Further, when students are properly mentored, it gives the trainees a satisfying internship experience that results in better internship outcomes (Knouse \& Fontenot, 2008).

Table 4. Assessment of the effectiveness of the pre-placement activities

\begin{tabular}{|c|c|c|}
\hline \multicolumn{1}{|c|}{ Pre-placement Evaluation } & $\begin{array}{c}\text { Wtd. } \\
\text { Ave }\end{array}$ & DE \\
\hline $\begin{array}{l}\text { 1. Comprehensiveness of the guidelines } \\
\text { provided by the University before deployment }\end{array}$ & 3.93 & MOA \\
\hline 2. Efficiency of placement procedures & 3.20 & A \\
\hline $\begin{array}{l}\text { 3. Sufficiency of orientation given by school } \\
\text { department }\end{array}$ & 3.62 & MOA \\
\hline Total Weighted Average Mean & 3.58 & MOA \\
\hline
\end{tabular}

Table 4 shows an assessment of the efficiency of the pre-placement activities, including orientation to students and the deployment process.

The result shows that the students moderately agree that the pre-placement activities were effective. It implies that the pre-placement activities of the University for the OJT program are effective and useful during their training.

At Kalinga State University, the students were given a two-day orientation seminar to students before deployment, which covers a topic in Personality Development, Work Ethics and Conduct, Customer 
Relations, and Filing and Records Management. After the topics were delivered, students will get the necessary documents needed during the training like training work plan, DTRs, narrative reports formats, and the parents' consent form and Waiver. Upon completion of required documents, deployment letters will be forwarded to host agencies. Orientation plays a significant role in on-the-job training's success (Catacutan \& Tuliao, 2020). It provides trainees' answers regarding their work arrangements and environment, the policies they have to follow, work ethics and etiquettes to observe, monitoring and evaluation, and others. Thus, it has to be regularly reviewed and continuously improved to maintain its relevance considering that work environments are also dynamic (Rosli et al., 2019).

Table 5 displays the assessment of the trainees on the efficiency of support the host company or the sponsoring agency had extended to them during their OJT. The results reveal that the students moderately agree that host agencies provided real work experience relevant to their course degree. This supports the findings of Renganathan et al. (2012) that students viewed their training experiences positively. Moreover, recent studies reveal that the role of training providers has a great role in achieving an effective OJT program (Chen \& Shen, 2012; Narayanan et al., 2010; Van Der Klink \& Streumer, 2002). To ensure an effective internship, Shoenfelt, Kottke \& Stone, 2012 suggest that the field and expertise of students should be primarily considered, and adequate supervision should be provided from the host agency. Also, training should focus on practical tasks that would lead to a real learning process (Phoebe, 2010; Renganathan et al., 2012; Stansbie et al., 2016).

Table 5. Assessment of the Host Agency Support

\begin{tabular}{|c|c|c|}
\hline Support of the host agency evaluation & $\begin{array}{c}\text { Wtd. } \\
\text { Ave. }\end{array}$ & DE \\
\hline $\begin{array}{c}\text { Relevance of Training provided to } \\
\text { course degree }\end{array}$ & 4.19 & MOA \\
\hline Structure of training program & 3.23 & $\mathrm{~A}$ \\
\hline Evaluation procedure was carried out & 3.93 & MOA \\
\hline $\begin{array}{c}\text { Provision of relevant workplace } \\
\text { experience }\end{array}$ & 4.12 & MOA \\
\hline $\begin{array}{c}\text { Treatment of supervisor during the } \\
\text { training }\end{array}$ & 3.78 & MOA \\
\hline $\begin{array}{c}\text { Provision of flexible time to attend } \\
\text { university activities }\end{array}$ & 4.04 & MOA \\
\hline Total Weighted Average Mean & 3.88 & MOA \\
\hline
\end{tabular}

Table 6. Assessment of the effectiveness of the OJT program in developing skills of the trainees

\begin{tabular}{|c|c|c|}
\hline Effectiveness of the OJT program evaluation & Wtd. Ave. & $\mathrm{DE}$ \\
\hline \multicolumn{3}{|l|}{ Academic skills indicators } \\
\hline Application of theoretical knowledge with practices in industry & 3.82 & MOA \\
\hline Enhancement in research and project skills & 3.65 & MOA \\
\hline Development in oral and presentation skills & 3.57 & MOA \\
\hline Opportunity to aspire future education and career & 4.40 & SA \\
\hline Total Weighted Average & 3.86 & MOA \\
\hline \multicolumn{3}{|l|}{ Personal skills indicators } \\
\hline Enhancement of creativity & 4.19 & MOA \\
\hline Opportunity execute problem solving activities & 4.24 & MOA \\
\hline Development of self confidence & 4.13 & MOA \\
\hline Opportunity to work independently & 4.09 & MOA \\
\hline Development of social interaction skill & 4.28 & SA \\
\hline Dealing with conflict effectively & 4.22 & MOA \\
\hline Total Weighted Average & 4.19 & MOA \\
\hline \multicolumn{3}{|l|}{ Entrepreneurial skills indicators } \\
\hline Development team working skills & 4.23 & MOA \\
\hline Acquisition of industry work culture & 4.15 & MOA \\
\hline Learning to prioritized task & 4.28 & SA \\
\hline Development managerial skills & 4.18 & MOA \\
\hline Development social and ethical responsibility & 4.26 & SA \\
\hline Development of leadership skills & 4.20 & SA \\
\hline Total Weighted Average & 4.22 & MOA \\
\hline
\end{tabular}


Table 5 displays the assessment of the trainees on the effectiveness of the OJT in developing the academic, personal and entrepreneurial skills of trainees. It can be gleaned on the table that the students moderately agree that the on-the-job training was effective in developing their skills. It implies that the students were able to gain actual work experience in their host agencies that lead to the development of their academic, personal, and entrepreneurial skills. This further implies that the host agencies successfully provided a meaningful experience to students and the University meetings its objectives for the OJT program.

Recent researches claim that after completing the OJT program, students acquired new knowledge and skills in research writing (Hynie et al., 2011); developed professional skills (Nghia \& My Duyen, 2018; Stansbie et al., 2016; \& Cooper et al., 2012), communication skills, (Jackson, 2013; Lim \& Mustafa, 2013), thinking skills (Joseph et al., 2015); and manifested change of attitude towards job (Bernardo et al., 2014). Also, some claim that OJT provided students the opportunity to solve problems in the workplace (Du-Babcock, 2016; Karunaratne \& Perera, 2015). Moreover, as supervisors provide trainees with opportunities to work with employees in the host agency and fellow trainees, students developed teamwork, learned to interact with different people, and prioritized tasks and leadership. Further, the training also developed the enterprise skills of students (Mihail, 2006).

While most research reveals that trainees manifested development in communications skills among trainees, Laguador et al. (2014) suggest the need to enhance both their written and oral skills. This is one of the skills employers look for during recruitment (McMurray et al., 2016).

\section{Conclusions}

Based on the findings, on-the-job training is effective in terms of enhancing personal skills and entrepreneurial skills to trainees while it needs further improvement in enhancing the enterprise skills of students. Generally, the students have a positive perception of the effectiveness of the on-the-job training program. With this positive feedback, the OJT program is indeed helpful to the students in honing their skills and enhancing their knowledge in their chosen fields.

The role played by the University in providing support to trainees and in the deployment process and support of host agencies were found to be crucial in the effectiveness of the OJT program as a whole. Trainees need the assistance of their advisers and supervisors as they go through the process of training. Pre-placement activities, particularly orientations to be conducted by the University and host-agency, are found to be very important for the students to be well-guided. Lastly, the host agency's role in the OJT program is vital in achieving the training's goals and objectives in providing real-work experience, making them ready for their future careers.

\section{Recommendations}

Considering the findings and conclusions drawn from the study, the following recommendations are submitted:

- The college, particularly the advisers of practicum subjects and OJT coordinator, should strengthen its support to all students for them to be properly guided in the execution of their tasks, avoid unfavorable incidents, and achieve a better actual learning experience through regular visits and monitoring. In addition, advisers should keep in touch with the supervisors to be well informed of the performances of the students.

- The college should strengthen its relationship with the host agencies by involving the different supervisors in the preparation of the On-the-Job training design for the students. This will also help supervisors be well informed and be properly guided as to the extent of support they need to give to the trainees.

- The pre-placement activities, particularly the orientation program, must be comprehensive that covers all necessary and practical information needed by the students. In addition, important information about the partner agencies must also be presented to give the trainees a background on what kind of agency they may work with.

- The University, through the practicum advisers, may consider accomplishing and securing the needed requirements, which may allow students to have their on-the-job training outside the Province to expose them to the different working atmosphere for a better learning experience.

For future researchers, more comprehensive studies with respect to the topic might be made to enhance and upgrade the OJT program of the different programs under the College of Business, Entrepreneurship and Accountancy.

\section{Acknowledgments}

The author would like to express her heartfelt thanks to all the students who patiently answered the survey questionnaire, the University administration for providing support in the conduct of the study, and to Professor Darin Jan C. Tindowen of the University of Saint Louis, Tuguegarao for his suggestions in improving the paper. 


\section{REFERENCES}

[1] Bernardo, A., Landicho, A., \& Laguador, J. M. (2014). On-the-Job Training Performance of Students from AB Paralegal Studies for SY 2013-2014. Studies in Social Sciences and Humanities, 1(4), 122-129. http://www.rassw eb.com

[2] Callanan, G. and Benzing, C. (2004), "Assessing the role of internships in the career -orientedyment of graduating college students," Education + Training, Vol. 46 No. 2, pp. 82-89. https://doi.org/10.1108/00400910410525261

[3] Catacutan, K. J. A., \& Tuliao, A. S. (2020). On-the-job training program evaluation of business administration and accountancy departments of the University of Saint Louis. Universal Journal of Educational Research, 8(1): 143-150, 2020.

[4] Chen, T. L., \& Shen, C. C. (2012). Today's intern, tomorrow's practitioner? - The influence of internship programmes on students' career development in the Hospitality Industry. Journal of Hospitality, Leisure, Sport, and Tourism Education. https://doi.org/10.1016/j.jhlste.201 2.02 .008

[5] Commission on Higher Education. (2017). CHED Memorandum Order. Retrieved fromhttps://ched.gov.ph/wp -content/uploads/2018/03/CMO-NO.-104-S.-2017.pdf

[6] D’Abate, C., Youndt, M., \& Wenzel, K. (2009). Making the most of an internship: An empirical study of internship satisfaction. Academy of Management Learning and Education. https://doi.org/10.5465/AMLE.2009.47785471

[7] Divine, R. L., Linrud, J. K., Miller, R. H., \& Wilson, J. H. (2007). Required Internship Programs in Marketing: Benefits, Challenges and Determinants of Fit. Marketing Education Review, 17(2), 45-52. https://doi.org/10.1080/10 528008.2007.11489003

[8] Du-Babcock, B. (2016). Bridging the Gap from Classroom-based Learning to Experiential Professional Learning: A Hong Kong Case. DINAMIKA ILMU. https://doi.org/10.21093/di.v16i2.527

[9] Gault, J., Leach, E., \& Duey, M. (2010). Effects of business internships on job marketability: The employers' perspective. In Education and Training. https://doi.org/10.1108/004009 11011017690

[10] Hynie, M., Jensen, K., Johnny, M., Wedlock, J., \& Phipps, D. (2011). Student internships bridge research to real-world problems. Education and Training. https://doi.org/10.1108/ 00400911111115753

[11] Jackson, D. (2013). Student Perceptions of the Importance of Employability Skill Provision in Business Undergraduate Programs. Journal of Education for Business.

[12] Jamil, N. A., Shariff, S. M., \& Abu, Z. (2013). Students' Practicum Performance of Industrial Internship Program. Procedia - Social and Behavioral Sciences. https://doi.org/10.1016/j.sbspro.2013.07.121

[13] Joseph, E., Valdez, C., Shiena, S., Alcantara, B., Pamintuan,
C. A., Relos, J. G., \& Castillo, R. C. (2015). Contributions of On-the-Job Training Program to the Skills, Personal Qualities, and Competencies of Tourism Graduates. Asia Pacific Journal of Multidisciplinary Research.

[14] Kingsley Karunaratne \& Niroshani Perera., "Students' Perception on the Effectiveness of Industrial Internship Programme," The International Conference on Global Business, Economics, Finance, and Social Sciences, Bangkok, Thailand, February 20-22, 2015.

[15] Knouse, S. B., \& Fontenot, G. (2008). Benefits of the business college internship: A research review. In Journal of Employment Counseling. https://doi.org/10.1002/j.2161-19 20.2008.tb00045.x

[16] Lim, H. E., \& Mustafa, M. M. (2013). Effectiveness of industrial training in improving students' generic skills. International Journal of Business and Society.

[17] Mason, G., Williams, G., \& Cranmer, S. (2009). Employability skills initiatives in higher education: What effects do they have on graduate labour market outcomes? Education Economics, 17(1), 1-30. https://doi.org/10.1080/ 09645290802028315

[18] McMurray, S., Dutton, M., McQuaid, R., \& Richard, A. (2016). Employer demands from business graduates. Education and Training. https://doi.org/10.1108/ET-02-201 4-0017

[19] Mengistu, D. G., \& Mahesh, G. (2019). Construction education in Ethiopia: Knowledge and skills level attained and effectiveness of internship program. Higher Education, Skills, and Work-Based Learning. https://doi.org/10.1108/H ESWBL-06-2018-0062

[20] Mihail, D. M. (2006). Internships at Greek universities: An exploratory study. Journal of Workplace Learning. https://doi.org/10.1108/13665620610641292

[21] Narayanan, V. K., Olk, P. M., \& Fukami, C. V. (2010). Determinants of Internship Effectiveness: An Exploratory Model. Academy of Management Learning \& Education. https://doi.org/10.5465/amle.9.1.zqr61

[22] Nghia, T. L. H., \& My Duyen, N. T. (2018). Internship-related learning outcomes and their influential factors: The case of Vietnamese tourism and hospitality students. Education and Training. https://doi.org/10.1108/E T-02-2017-0030

[23] Phoebe, W. K. (2010). Determinants of Internship Effectiveness for University Students in Hong Kong. In the School of Business.

[24] Renganathan, S., Karim, Z. A. B. A., \& Li, C. S. (2012). Students' perception of industrial internship programme. Education and Training.https://doi.org/10.1108/004009112 11210288

[25] Rosli, M. H., Selangor, U., \& Alam, S. (2019). Addressing the Expectation Gap in Internship Program: Addressing the Expectation Gap in Internship Program: Perspectives of Accounting. August 2017.

[26] Stansbie, P., Nash, R., \& Chang, S. (2016). Linking internships and classroom learning: A case study examination of hospitality and tourism management students. Journal of Hospitality, Leisure, Sport, and Tourism 
Education. https://doi.org/10.1016/j.jhlste.2016.07.001

[27] Streumer, J. N., \& Kho, M. (2006). The world of work-related learning. In Work-Related Learning. https://doi.org/10.1007/1-4020-3939-5_1
[28] Van Der Klink, M. R., \& Streumer, J. N. (2002). Effectiveness of on-the-job training. Journal of European Industrial Training. https://doi.org/10.1108/030905902104 22076 